\title{
STUDI KELAYAKAN BISNIS PADA PERENCANAAN USAHA CAFÉ KULINER DI KOTA SURABAYA
}

\author{
Achmad Daengs, GS \\ email : adaengsgs@univ45sby.ac.id \\ Fakultas Ekonomi Universitas 45 Surabaya \\ Diah Rani Nartasari \\ e-mail :narta72@gmail.com \\ Akademi Sekretarie Manajemen Indonesia Surabaya \\ Heri T Prasetia \\ email : samudera_indonesia27heri@yahoo.com \\ Fakultas Ekonomi Universitas 45 Surabaya
}

\begin{abstract}
Feasibility study is the tool that is able to be consideration materials in making the decisions to receive or reject the investment proposed in developing or establishing the project/business planning. The research about analysis of business feasibility, instead of to know whether it is feasible or not of the value of investment criteria, it is also to know the amount of investment funds that needed, the existing market share, and any constraints that will be possible to occurs in the process of establishing that type of business. As for the objectives that will be obtained from this research is to conduct the analysis of business feasibility as viewed from several aspects, that are financial aspect, and social aspect.
\end{abstract}

Keywords : Net Present Value (NPV), Internal Rate of Return (IRR), Profitability Index (PI), Payback Period (PP), and Break Even Point (BEP)

\section{PENDAHULUAN}

Studi kelayakan dewasa ini menjadi kebutuhan penting bagi masyarakat bisnis maupun masyarakat umum yang baru melangkah dalam dunia wirausaha, nacpun yang hendak mengembangkan usaha bisnis mereka menjadi lebih luas dan maju. Banyak cara yang dapat dilakukan oleh masyarakat untuk membuka dan mengembangkan usaha untuk memperbaiki kondisi perekonomian mereka.

Studi kelayakan merupakan suatu alat yang mampu menjadi bahan pertimbangan dalam mengambil suatu keputusan untuk menerima atau menolak suatu usulan investasi dalam membangun atau mendirikan rencana proyek/usaha.

Pengertian layak dalam penilaian sebagai studi kelayakan maksudnya adalah kemungkinan dari gagasan usaha/proyek yang akan dilaksanakan memberikan manfaat (benefit), baik dalam arti financial benefit maupun dalam arti social benefit. Layaknya suatu gagasan usaha/proyek dalam arti social benefit, tidak selalu menggambarkan layak dalam konteks financial benefit dan begitu pula sebaliknya, hal ini tergantung dari segi penilaian yang dilakukan, Ibrahim (2009).

Ditengah-tengah kondisi perekonomian yang serba sulit ini, peluang untuk mendapatkan pekerjaan menjadi tambah sulit. Berbagai cara ditempuh orang agar mereka tidak menjadi pengangguran. Salah satu alternatifnya adalah memulai sebuah bisnis atau usaha yang dapat menghasilkan manfaat dan keuntungan. Ada banyak peluang yang bisa dilakukan dan 
semuanya ada di depan mata kita, tetapi masalahnya adalah cara kita memaksimalkan peluang bisnis tersebut. Mungkin modal merupakan salah satu alasan utama untuk memulai sebuah bisnis baru. Namun segala upaya dapat dimaksimalkan dengan keahlian yang dimiliki oleh para calon pemilik usaha dalam membangun usahanya.

Sebelumnya usaha ini hanya sebuah warung tenda dalam lingkungan Pedagang Kaki Lima (PKL) di daerah Surabaya, sempat mengalami kendala tempat usaha atas peraturan pemerintah kota yang melarang aktivitas PKL di tengah kota. Hal ini menyebabkan kelangsungan usaha tersebut sempat mengalami kemacetan, usaha tersebut tutup selama beberapa tahun. Alasan ini yang menyebabkan Pengusaha memulai lagi usahanya dengan konsep yang berbeda, salah satunya dengan menyewa lahan baru sebagai lokasi usaha dengan sewa kontrak pada salah satu Rumah Toko (Ruko) di sekitar wilayah Surabaya.

Berdasarkan hal tersebut maka dilakukan penelitian tentang studi kelayakan bisnis terhadap usaha café yang ditinjau dari aspek-aspek yang terkait dengan studi kelayakan.

Usaha yang semakin berkembang menjadi satu alasan untuk memperoleh ramalan (forecasting) dalam rencana mewujudkan kegiatan bisnis skala kecil yang akan dibangun di tengah kota Surabaya, apakah investasi pada pendirian usaha ini layak untuk dilaksanakan dan dalam jangka waktu berapa lama usaha depot ini dapat mengembalikan investasinya. Untuk itu perlu dilakukannya suatu penelitian tentang studi kelayakan bisnis yang akan ditinjau dari berbagai aspek yang terkait. Usaha ini merupakan suatu konsep usaha perorangan yang berencana menjual makanan khas dengan menu khas Indonesia, dalam rencana pendirian proyek dengan pengembangan menu yang lebih spesifik dan bertujuan untuk memperkuat citra café dalam upaya memperoleh keunggulan kompetitif dari para pesaing disekitar tengah kota.

Studi kelayakan ini juga untuk mengetahui besarnya dana investasi yang dibutuhkan, pangsa pasar yang ada, dan kendala apa saja yang mungkin terjadi dalam proses mendirikan jenis usaha café tersebut. Adapun tujuan yang ingin dicapai dari hasil penelitian ini adalah untuk melakukan analisa kelayakan usaha ditinjau dari berbagai aspek, yaitu aspek pasar, aspek teknis, aspek manajemen, aspek finansial atau keuangan, serta aspek sosial.

\section{KAJIAN PUSTAKA}

Menurut Kasmir dan Jakfar (2009), studi kelayakan bisnis adalah suatu kegiatan penelitian yang dilakukan secara mendalam tentang rencana bisnis, dalam rangka menentukan layak atau tidaknya rencana bisnis tersebut dijalankan, Layak dalam arti akan memberikan keuntungan tidak hanya bagi perusahaan yang menjalankannya, tetapi juga bagi investor, kreditor, pemerintah dan masyarakat luas.

Menurut Ibrahim (2009), studi kelayakan bisnis adalah kegiatan untuk menilai sejauh mana manfaat yang dapat diperoleh dalam melaksanakan suatu kegiatan usaha atau proyek.

Studi kelayakan yang juga sering disebut dengan feasibility study nerupakan bahan pertimbangan dalam mengambil suatu keputusan, apakah menerima atau menolak dari suatu gagasan usaha / proyek yang direncanakan. Pengertian layak dalam penilaian studi kelayakan adalah kemungkinan dari gagasan usaha / proyek yang akan dilaksanakan memberikan manfaat (benefit), baik dalam arti finansial maupun dalam arti sosial benefit, Ibrahim (2009).

Tujuan dilakukannya analisis bisnis, Gray dan Larson (2007) adalah :

1) Untuk mengetahui tingkat keuntungan yang dapat dicapai melalui investasi dalam suatu proyek;

2) Menghindari pemborosan sumber-sumber daya, yaitu menghindari pelaksanaan kegiatan yang tidak menguntungkan; 
3) Mengadakan penilaian terhadap peluang investasi yang ada sehingga dapat memilih alternatif kegiatan yang paling menguntungkan;

4) Menentukan prioritas investasi.

Menurut Kasmir dan Jakfar (2008), investasi didefinisikan sebagai pengorbanan atau penanaman sejumlah dana pada masa sekarang untuk suatu usaha pada saat sekarang dan mengharapkan pengembalian dengan disertai keuntungan pada masa yang akan datang.

\section{Manfaat Studi Kelayakan Bisnis}

Manfaat studi kelayakan bisnis, Umar (2003), adalah :

a. Pihak Investor. Calon investor memiliki kepentingan langsung terhadap keuntungan yang akan diperoleh, serta jaminan keselamatan atas modal yang ditanamkannya.

b. Pihak Kreditor. Pihak bank sebagai pemberi pinjaman perlu mengkaji ulang studi kelayakan bisnis yang telah dibuat, misalnya mengenai bonafiditas dan tersedianya agunan yang dimiliki perusahaan.

c. Pihak Manajemen. Pihak manajemen perlu mempelajari studi kelayakan bisnis yang dibuat, misalnya dalam hal pendanaan, berapa yang dialokasikan dari modal sendiri, serta rencana pendanaan dari investor dan kreditor.

d. Pihak Pemerintah dan Masyarakat. Penyusunan studi kelayakan bisnis yang memperhatikan dan membantu kebijakan pemerintah akan diprioritaskan untuk dibantu, misalnya dengan subsidi dan keringanan lain.

e. Bagi Tujuan Pembangunan Ekonomi. Dalam menyusun studi kelayakan bisnis perlu juga dianalisis manfaat yang akan didapat dan biaya yang akan ditimbulkan terhadap perekonomian nasional.

\section{Aspek-Aspek Studi Kelayakan Bisnis}

Menurut Husnan dan Muhammad (2000), secara umum aspek-aspek yang diteliti dalam studi kelayakan bisnis meliputi :

1) aspek pasar,

2) aspek teknis,

3) aspek finansial,

4) aspek manajemen,

5) aspek hukum,

6) aspek ekonomi, dan sosial.

Meskipun belum ada kesepakatan tentang aspek apa saja yang perlu diteliti untuk menentukan layak atau tidaknya suatu bisnis, maka perlu ditentukan kelayakan berdasarkan seluruh aspek yang akan dinilai. Jika ditemukan aspek yang kurang layak, maka dilakukan perbaikan agar memenuhi kriteria yang layak. Namun, apabila tidak dapat memenuhi kriteria tersebut, sebaiknya usaha jangan dijalankan.

\section{Aspek Pasar}

Pengkajian aspek pasar penting untuk dilakukan, karena tidak ada bisnis yang berhasil tanpa adanya permintaan atas barang dan jasa yang dihasilkan oleh suatu bisnis yang dijalankan.

Pemasaran adalah suatu prosessosial dan manajerial dimana individu dan kelompok mendapatkan kebutuhan dan keinginan mereka dengan menciptakan, menawarkan, dan bertukar sesuatu yang bernilai satu sama lain, Kotler (2007).

Aspek pasar mempelajari tentang :

1. Permintaan 
Permintaan adalah kegiatan yang didukung oleh kemampuan untuk membeli, dengan kata lain permintaan akan terjadi apabila didukung oleh kemampuan membeli oleh konsumen untuk memperoleh barang dan jasa yang ditawarkan. Faktor-faktor yang mempengaruhi permintaan, antara lain harga barang itu sendiri, harga barang lain baik sebagai substitusi maupun komplementer, pendapatan, selera, jumlah penduduk, dan akses untuk mendapatkan barang dan jasa yang ditawarkan.

2. Penawaran

Penawaran adalah jumlah barang dan jasa yang ditawarkan produsen kepada konsumen pada berbagai tingkat harga pada suatu waktu tertentu. Faktor-faktor yang mempengaruhi penawaran, diantaranya adalah harga barang dan jasa itu sendiri, harga barang lain, teknologi, harga input, tujuan perusahaan, atau akses.

3. Pemasaran

Kotler (2007:23) mendefinisikan bahwa bauran pemasaran adalah seperangkat alat pemasaran yang digunakan perusahaan secara terus-menerus untuk mencapai tujuan di pasar sasaran.

\section{Strategi Lokasi dan Distribusi}

Hal-hal yang perlu diperhatikan dalam pemilihan dan penentuan lokasi dengan pertimbangan sebagai berikut, yaitu dekat dengan kawasan industri dekat dengan lokasi perkantoran, dekat dengan lokasi pasar, dekat dengan pusat pemerintahan, dekat dengan lokasi perumahan atau masyarakat, mempertimbangkan jumlah pesaing yang ada di suatu lokasi, sarana dan prasarana seperti jalan, pelabuhan, listrik, dan lain-lain, Kasmir dan Jakfar (2003).

Menurut Prassetya A. (2010), bahwa terdapat empat filosofi pemasaran yang merupakan falsafah penuntun usaha pemasaran suatu organisasi bisnis, antara lain :

a. Konsep Produksi

Konsep ini menyatakan bahwa konsumen akan menyukai produk yang tersedia, sehingga orientasi manajemen adalah meningkatkan efisiensi produksi dan efisiensi distribusi. Karena asumsinya adalah bahwa konsumen (pasti) menyukai produk yang tersedia, maka usaha manajemen tentulah membuat produk yang sebanyak-banyaknya, dengan demikian akan dicapai efisiensi produksi.

b. Konsep Produk

Konsep produk memilih asumsi bahwa konsumen hanya menyukai produk yang berkualitas bagus, sehingga orientasi manajemen adalah menciptakan produk dengan kualitas yang bagus pula, agar menjadi produk yang "terpilih".

c. Konsep Penjualan

Konsep penjualan mempunyai asumsi bahwa betapapun bagusnya kualitas suatu produk, apabila ia tidak dikomunikasikan kepada pasar, maka tidak akan dibeli oleh pasar. Sehingga orientasi manajemen adalah melakukan "promosi gencar".

d. Konsep Pemasaran

Konsep pemasaran mempunyai asumsi bahwa kunci untuk mencapai sasaran organisasi adalah menentukan kebutuhan dan keinginan pasar, kemudian memuaskan kebutuhan dan keinginan tersebut secara lebih efektif dan lebih efisien dibandingkan dengan para pesaingnya. Dengan demikian, manajemen tak boleh hanya berorientasi pada manajemen promosi (promotion) saja, namun juga penciptaan produk yang sesuai dengan kebutuhan dan keinginan pasar (product), penetapan harga (pricing), dan bagaimana mendistribusikannya (place). Konsepsi inilah yang biasa dikenal dengan sebutan Marketing Mix, atau 4P (product, price, promotion, place), atau bauran pemasaran. 


\section{Aspek Teknis}

Aspek teknis berkenaan dengan proses pembangunan proyek secara teknis dan pengorganisasiannya setelah proyek tersebut selesai dibangun, Husnan dan Muhammad (2000). Aspek teknis berkaitan dengan pemilihan lokasi proyek, jenis mesin atau peralatan lainnya yang sesuai dengan kapasitas produksi, tata letak, dan pemilihan teknologi yang paling menguntungkan.

Jadi, analisis dari aspek teknis dan teknologi adalah untuk menilai kesiapan perusahaan dalam menjalankan usahanya dengan menilai ketetapan lokasi, luas produksi dan tata letak serta kesiagaan mesin-mesin yang akan digunakan. Secara keseluruhan aspek teknis dan teknologi ini dinilai bekerja secara efisien atau tidak, karena pada akhirnya efisiensilah yang akan menentukan salah satu faktor besar kecilnya laba yang akan diperoleh perusahaan, Kasmir dan Jakfar (2009).

Secara umum ada beberapa hal yang hendak dicapai dalam penilaian aspek teknis maupun teknologi, yaitu agar perusahaan dapat menentukan lokasi yang :epat, baik untuk lokasi pabrik, gudang, cabang, maupun kantor pusat, agar perusahaan dapat menentukan tata letak yang sesuai dengan proses produksi yang dipilih, sehingga dapat memberikan efisiensi, agar perusahaan bisa menentukan teknologi yang paling tepat dalam menjalankan produksinya, agar perusahaan bisa menentukan metode persediaan yang paling baik untuk dijalankan sesuai dengan bidang usahanya, agar dapat menentukan kualitas tenaga kerja yang dibutuhkan sekarang dan di masa yang akan datang, Kasmir dan Jakfar (2009).

\section{Aspek Manajemen}

Analisis terhadap aspek manajemen dilakukan untuk memperoleh sebaran mengenai kemampuan pegawai dalam melaksanakan usaha yang dijalankan. Pada umumnya tujuan yang tercantum dalam studi kelayakan adalah tujuan makro yang masih perlu untuk dijabarkan dalam bentuk mikro sehingga jelas apa yang akan dikerjakan. Berdasarkan pada uraian ini, tugas pokok yang harus dilakukan adalah menyangkut dengan fungsi manajemen antara lain perencanaan, pengorganisasian, pengadaan tenaga kerja, pengarahan pekerjaan, dan pelaksanaan pengawasan, Ibrahim (2009).

Studi aspek manajemen meliputi penyusunan rencana kerja, siapa saja yang terlibat, bagaimana mengkoordinasi dan mengawasi pelaksanaan usaha, menentukan secara efektif dan efisien mengenai bentuk badan usaha, jenis-jenis pekerjaan, struktur organisasi, serta pengadaan tenaga kerja yang dibutuhkan. Selain itu, menurut Suryana (2003) perlu juga diperhatikan apakah usaha akan dikelola sendiri atau melibatkan orang lain secara profesional. Penentuan faktor manajemen dalam usaha yang akan dibangun dengan menetapkan kegiatan rerencanaan (planning), pengorganisasian (organizing), pelaksanaan (actuating), dan pengendalian (controlling).

\section{Aspek Sosial}

Analisis sosial dilakukan untuk mengetahui dampak yang ditimbulkan dari adanya proyek bisnis yang hendak didirikan, apakah dengan keberadaan proyek memberikan dampak pada suatu wilayah menjadi semakin ramai, lalu lintas semakin lancar, adanya jalur komunikasi, penerangan listrik, pendidikan masyarakat setempat, dan lainnya.

Tujuan utama perusahaan adalah mencari keuntungan yang sebesar-besarnya. Namun demikian, perusahaan tidak dapat bergerak sendiri tanpa dukungan pihak lain dalam lingkungannya sehingga dalam interaksi dan perkembangan suatu usaha dipastikan harus memiliki tanggung jawab sosial. Berdasarkan analisis tersebut, hendaknya proyek bisnis memiliki manfaat-manfaat sosial yang dapat diterima oleh masyarakat, seperti : 
a. Membuka lapangan kerja baru

Dengan adanya suatu bisnis yang hendak dijalankan turut serta membuka lapangan kerja baru yang dapat membuka respon masyarakat untuk memperoleh pekerjaan.

b. Melaksanakan alih teknologi

Dengan dilakukannya alih tekhnologi kepada pekerja dengan berbagai cara pelatihan yang terprogram dengan baik maka diharapkan dapat meningkatkan "skil" atau kemampuan pekerja dan juga sikap mental sebagai tenaga kerja yang dapat diandalkan serta berkompeten.

c. Meningkatkan ekonomi masyarakat

Dengan adanya pembangunan proyek bisnis diharapkan dapat turut serta mengurangi angka pengangguran, menambah pengetahuan dan informasi terkait dengan kepentingan konsumsi masyarakat sehingga sedikit banyak dapat membantu meningkatkan taraf hidup masyarakat sekitar.

\section{Aspek Finansial}

Adalah suatu analisis yang membandingkan apakah suatu proyek menguntungkan selama umur proyek, Husnan dan Muhammad (2000). Analisis finansial berkaitan dengan sumber dana (investasi) yang akan diperoleh dan proyeksi pengembaliannya dengan tingkat biaya modal (biaya yang akan dikeluarkan) dan sumber dana yang bersangkutan.

\section{Biaya Investasi}

Investasi merupakan penanaman modal dalam suatu kegiatan yang memiliki jangka waktu relatif panjang dalan berbagai bidang usaha. Jangka waktu investasi biasanya lebih dari satu tahun, terutama digunakan untuk pembelian aktiva tetap.

Komponen yang terkandung dalam biaya kebutuhan investasi biasanya disesuaikan dengan jenis usaha yang akan dijalankan. Secara garis besar biaya kebutuhan investasi meliputi sebagai berikut biaya pra-investasi, yang terdiri dari biaya pembuatan studi, biaya pengurusan izin-izin. Biaya aktiva tetap dibagi menjadi dua, yaitu aktiva tetap berwujud antara lain tanah, mesin-mesin, bangunan, peralatan, investasi kantor. Aktiva tetap tidak berwujud antara lain good will, hak cipta, lisensi, dan merek dagang. Biaya Operasional, yang terdiri dari upah atau gaji karyawan, biaya listrik, biaya telepon, biaya air, biaya pemeliharaan, pajak, premi asuransi, biaya pemasaran dan biaya lain-lainnya, Kasmir dan Jakfar (2009).

\section{Net Present Value (NPV)}

Diartikan sebagai nilai sekarang dari arus kas yang ditimbulkan oleh investasi. Dalam menghitung $N P V$, perlu ditentukan tingkat suku bunga yang relevan.

Kriteria kelayakan investasi berdasarkan $N P V$ yaitu :

- $N P V>0$, artinya pekerjaan sudah dinyatakan menguntungkan dan dapat dilaksanakan.

- $N P V<0$, artinya pekerjaan tidak menghasilkan nilai biaya yang dipergunakan. Dengan kata lain proyek tersebut merugikan dan sebaiknya tidak dilaksanakan.

- $N P V=0$, artinya pekerjaan mampu mengembalikan persis sebesar modal sosial opportunity cost faktor produksi normal, dengan kata lain pekerajaan tersebut tidak untung dan tidak rugi.

\section{Profitability Index (PI)}

Merupakan perbandingan antara seluruh kas bersih nilai sekarang dengan investasi awal. Teknik ini juga sering disebut dengan model rasio manfaat biaya (Net B/C Ratio). 
PI atau Net B/C Ratio menyatakan besarnya pengembalian terhadap setiap catu satuan biaya yang telah dikeluarkan selama umur proyek. $P I$ merupakan angka perbandingan antara present value $(P V)$ dari benefit yang positif dengan $\mathrm{PF}$ dari benefit yang negatif. Kriteria investasi berdasarkan $P I$ adalah :

- $\quad P I>1$, maka $N P V>0$. proyek menguntungkan.

- $P I<1$, maka $N P V<0$. proyek tidak menguntungkan.

- $P I=1$, maka $N P V=0$. proyek tidak untung dan tidak rugi.

\section{Internal Rate of Return (IRR)}

$I R R$ adalah tingkat bunga yang menyamakan $P V$ kas keluar yang diharapkan dengan $P V$ kas masuk yang diharapkan atau dapat diartikan sebagai tingkat bunga yang menyebabkan $N P V=0$. Menurut Johan (2011), IRR merupakan metode penilaian kelayakan proyek dengan menggunakan perluasan metode nilai sekarang. Pada posisi $N P V=0$ akan diperoleh tingkat prosentase IRR.

Suatu investasi dikatakan layak, apabila nilai $I R R$ lebih besar dari tingkat suku bunga yang berlaku dan sebaliknya jika nilai $I R R$ lebih kecil dari tingkat suku bunga yang berlaku, maka proyek tersebut tidak layak untuk dilaksanakan. Beberapa kelebihan dari penggunaan metode ini antara lain, sudah menghitung nilai uang yang disebabkan oleh faktor waktu, menghitungkan usia ekonomis proyek, memperhitungkan adanya nilai sisa proyek, bank lebih mudah menentukan persentase tingkat suku bunga maksimum yang bisa ditutup proyek, Johan (2011).

\section{Payback Period}

Adalah salah satu metode dalam menilai kelayakan usaha yang digunakan untuk mengukur periode waktu pengembalian modal yang digunakan. Semakin cepat modal dapat kembali, maka semakin baik suatu proyek untuk diusahakan karena modal yang digunakan akan cepat kembali dan digunakan untuk membiayai kegiatan lain, Husnan dan Muhammad (2000).

\section{Break Event Point}

Adalah suatu kondisi pada saat tingkat produksi atau besarnya pendapatan sama dengan besarnya pengeluaran perusahaan, sehingga pada saat itu perusahaan tidak mengalami keuntungan maupun kerugian, Mulyadi (1997).

Menurut Pujawan (2009), analisis titik impas pada permasalahan produksi digunakan untuk menentukan tingkat produksi yang bisa mengakibatkan perusahaan berada pada kondisi impas. Ada tiga komponen biaya yang dipertimbangkan dalam analisis ini, yaitu :

a. Biaya-biaya tetap (Fixed Cost), yaitu biaya-biaya yang besarnya tidak dipengaruhi oleh volume produksi. Beberapa biaya yang termasuk biaya tetap antara lain biaya gedung, biaya tanah, biaya mesin, biaya peralatan, dan sebagainya.

b. Biaya-biaya variabel (Variable Cosi), yaitu biaya-biaya yang besarnya tergantung terhadap volume produksi. Biaya-biaya yang tergolong biaya variabel diantaranya adalah biaya bahan baku dan biaya tenaga kerja langsung.

c. Biaya total (Total Cosi), yaitu jumlah dari biaya-biaya tetap dan biaya-biaya variabel. Analisa menurut $B E P$ bertujuan untuk memberikan suatu proyeksi kepada pemilik modal atau pelaku usaha agar dapat memberikan informasi penjualan yang harus dicapai dalam suatu periode tertentu maupun penjualan dalam kapasitas (produk/harga) tertentu. 


\section{Analisis Sensitivitas}

Suatu analisis untuk dapat melihat pengaruh-pengaruh yang akan terjadi akibat keadaan yang berubah-ubah. Analisis sensitivitas bertujuan untuk melihat apa yang akan terjadi dengan hasil analisis suatu usaha jika terjadi kesalahan atau perubahan pada perhitungan biaya dan penjualan. Setiap kemungkinan yang terjadi dilihat pengaruhnya terhadap usaha. Implikasi dari kondisi tersebut harus diadakan analisis kembali untuk berbagai kemungkinan yang terjadi pada kondisi riil. Analisis usaha umumnya berdasarkan pada nilai dari perkiraanperkiraan yang dapat terjadi pada masa mendatang, Sutojo (1983). Hasil penggunaan metode analisa kepekaan adalah perkiraan jumlah permintaan yang sifatnya optimisis, pesimistis dan realistis, Sutojo (2000).

\section{METODE PENELITIAN}

\section{Kerangka Konseptual}

Kerangka konseptual penelitian ditunjukkan dalam Gambar 1. Dalam aspek keuangan akan dilakukan penilaian akan kelayakan usaha berdasarkan Internal Rate of Return (IRR), Net Present Value (NPV), Break Even Point (BEP), Profitability Index (PI), dan Payback Period (PP). Selain itu, akan dilakukan juga analisis sensitivitas.

\section{Analisis Data dan Pembahasan}

Pengolahan data dilakukan dengan menggunakan software Microsoft Excel 2007. Analisis Data dilakukan secara kualitatif dan kuantitatif. Analisis di dilakukan untuk menganalisis aspek pasar, aspek hukum, aspek manajemen, aspek teknis/operasi, dan aspek ekonomi dan sosial, dimana analisis disesuaikan dengan teori yang ada, Alhusna (2011).

Analisis kuantitatif digunakan untuk menganalisis aspek keuangan yang terdiri berbagai nilai kriteria investasi seperti Internal Rate of Return (IRR), Net Present Value (NPV), Profitability Index (PI) dan Payback Period (PP),

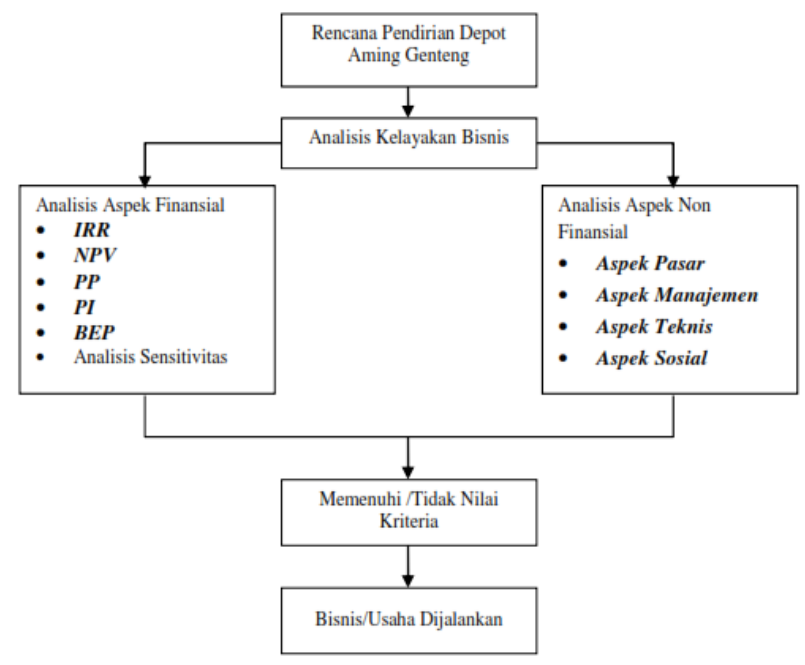

Gambar 1 : Kerangka Pemikiran Tahapan Penelitian 


\section{Aspek Manajemen}

Dalam usaha untuk melaksanakan proyek/usaha yang telah dinyatakan feasible untuk dikembangkan, peranan manajemen tidak dapat diabaikan untuk keberhasilan dari usaha tersebut. Bagaimanapun baiknya prospek dari gagasan usaha/proyek yang dilaksanakan, tanpa didukung dengan manajemen yang baik, tidak mustahil akan mengalami kegagalan. Berdasarkan pada masalah ini pula, perlu diuraikan disini tugas-tugas penting yang perlu dilaksanakan agar tujuan yang telah tercantum dalam studi kelayakan dapat tercapai, Ibrahim (2009).

\section{Aspek Keuangan}

Biaya investasi adalah biaya yang diperlukan dalam pembangunan proyek, terdiri dari pengadaan tanah, gedung, mesin, peralatan, biaya pemasangan, biaya feasibility study, dan biaya lainnya yang berhubungan dengan pembangunan proyek, Ibrahim (2009).

Masih menurut Ibrahim (2009), modal kerja adalah biaya yang dikeluarkan untuk membiayai kegiatan usaha setelah pembangunan proyek siap, terdiri dari biaya tetap (fixed cost), dan biaya tidak tetap (variable cost).

Untuk memenuhi kebutuhan biaya investasi dan modal kerja dapat melalui dua sumber, yaitu sumber dari dalam perusahaan dan sumber dari luar perusahaan. Sumber dari dalam perusahaan adalah modal yang berasal dari para investor sendiri atau modal yang dihimpun atas penjualan saham. Modal dari luar perusahaan adalah modal yang berasal dari bank, produsen peralatan, dan lembaga keuangan lainnya.

\section{Net Present Value (NPV)}

Rumusan yang biasa digunakan dalam menghitung $N P V$ adalah sebagai berikut :

$$
\mathrm{NPV}=\sum_{\mathrm{t}=1}^{\mathrm{n}} \frac{\mathrm{Bt}-\mathrm{Ct}}{(1+\mathrm{i})}
$$

Dimana :

$$
\begin{aligned}
& \mathrm{Bt}=\text { Manfaat pada tahun } \mathrm{t}(\mathrm{Rp}) \\
& \mathrm{Ct}=\text { Biaya pada tahun } \mathrm{t}(\mathrm{Rp}) \\
& \mathrm{N}=\text { Umur Proyek (Tahun) } \\
& \mathrm{I}=\text { Discount Rate }(\%)
\end{aligned}
$$

\section{Internal Rate of Return (IRR)}

Tingkat pengembalian hasil internal (IRR) merupakan alat untuk mengukur tingkat pengembalian hasil internal, sedangkan cara penghitungan IRR biasa digunakan dengan rumus :

$$
I R R=i_{1}+\frac{N P V_{1}}{N P V_{1}-N P V_{2}} x\left(i_{2}-i_{1}\right)
$$

Dimana :

$$
\begin{array}{ll}
i_{1} & =\text { Nilai Diskonto pada saat } \operatorname{NPV}_{1}(\%) \\
i_{2} & =\text { Nilai Diskonto pada saat } \operatorname{NPV}_{2}(\%) \\
N P V_{1} & =\text { Nilai NP V Positif }(\mathrm{Rp}) \\
N P V_{2} & =\text { Nilai NPV Negatif }(\mathrm{Rp})
\end{array}
$$

\section{Payback Period (PP)}

Perhitungan Payback Period dapat dilakukan dengan menggunakan rumus : 
$\mathrm{PP}=\frac{\text { Capital Outlays }}{\text { Proceeds }} \times 1$ tahun

Dimana :

Capital Outlays $=$ Nilai Investasi

Proceeds $\quad=$ Kas Masuk Bersih

1 tahun $\quad=12$ bin

\section{Profitabilty Index (PI)}

Berikut rumus yang digunakan untuk perhitungan $P I$ :

$\mathrm{PI}=\frac{\mathrm{PV} \text { of Proceeds }}{\text { Initial Outlays }} \geq 1$

Dimana :

$\mp$ PV of Proceeds = Total Kas Masuk Bersih

Initial Outlays $=$ PV Investasi Awal

\section{Break Event Point}

Merupakan teknik analisa yang digunakan untuk mengetahui titik impas dari penjualan produk yang dapat mengembalikan modal awal yang digunakan untuk usaha dalam jangka waktu umur proyek. Hal ini untuk memudahkan penghitungan nilai pengembalian investasi pada tingkat modal, karena dalam kondisi ini perusahaan tidak mengalami keuntungan maupun kerugian (pulang pokok). Titik pulang pokok (Break Even Point) adalah titik keseimbangan antara total penerimaan dengan total pengeluaran atau TR $=\mathrm{TC}$, Ibrahim (2009).

Jadi BEP merumuskan berapa nilai penjualan yang harus dicapai untuk mengembalikan modal atau pulang pokok, untuk perhitungan secara sederhana dapat digunakan rumus sebagai berikut :

$$
\mathrm{BEP}=\frac{\text { Biaya Tetap }}{\text { Harga }- \text { Biaya Variabel }}
$$

\section{PEMBAHASAN}

\section{Analisis Aspek Finansial}

Digunakan untuk menganalisis kelayakan suatu proyek atau usaha dari segi keuangan. Dalam aspek finansial atau keuangan akan dilakukan penilaian kriteria investasi berdasarkan Internal Rate of Return (IRR), Net Present Value (NPV), Breakevent Point (BEP), Profitability Index (PI), dan Payback Period (PP). Untuk menganalisis kriteria tersebut, digunakan arus kas (cashflow) untuk mengetahui besarnya manfaat yang diterima dan biaya yang dikeluarkan.

Selain itu juga dilakukan analisis laba rugi yang akan menghasilkan komponen pajak yang merupakan pengurangan dalam cashflow perusahaan. Setelah diketahui pajak maka dilakukan penyusunan cashflow sebagai dasar perhitungan kriteria investasi. Kriteria investasi akan menunjukan layak tidaknya usaha dari sisi finansial. Untuk mencari batas maksimal suatu perubahan sehingga dengan batas tersebut usaha masih dikatakan layak maka dilakukan analisis sensitivitas dengan metode penghitungan trial and error. 


\section{Biaya Kebutuhan Investasi}

1. Pola investasi 1, menggunakan modal pinjaman sebesar $100 \%$, pola ini dianggap memungkinkan jika pihak depot melakukan pinjaman dan pihak bank mau memberikan pinjaman atas biaya investasi.

2. Pola investasi 2, yaitu jika pihak depot tidak melakukan pinjaman dan mendanai kebutuhan investasi usaha perusahaan $100 \%$ atas modal sendiri. Cara ini sebagai antisipasi seandainya pihak depot tidak memperoleh dana dari pihak kreditur (bank).

\section{Biaya Tetap}

Biaya tetap adalah biaya yang dikeluarkan setiap tahun yang besarnya tidak berpengaruh langsung terhadap jumlah output yang dihasilkan. Biaya tetap yang dikeluarkan oleh Perusahaan Surabaya meliputi sewa tempat, biaya gaji, biaya telepon dan transportasi.

a) Biaya Sewa Tempat

Biaya sewa tempat sebagai lokasi usaha yang dikeluarkan oleh Perusahaan yaitu sebesar Rp. 20.000.000,- pertahun, sehingga total pengeluaran untuk sewa tempat selama umur proyek 5 tahun adalah Rp. 100.000.000,-

b) Biaya Gaji

Berdasarkan hasil wawancara dengan pihak depot bahwa asumsi pengeluaran untuk gaji para pekerja dalam hal ini penulis membedakan biaya berdasarkan posisi atau jabatan karyawan Perusahaan.

c) Biaya Telepon dan Transportasi

Berdasarkan hasil wawancara besarnya biaya telepon dan biaya transpostasi usaha masing masing adalah $\mathrm{Rp} 100.000,-+$ Rp. 195.000,- $=$ Rp 295.000,- perbulan. Sehingga dalam setahun total biaya yang dikeluarkan adalah $\mathrm{Rp} 295.000,-\mathrm{x} 12$ bulan $=\mathrm{Rp} 3.540 .000,-$

d) Biaya Pinjaman

Dalam skenario 1 jika pendanaan biaya investasi usaha Perusahaan menggunakan modal pinjaman dari bank/kreditur sebesar Rp. 50.016.600,- maka dapat ditentukan nilai angsuran selama umur proyek dengan menggunakan rumus :

$$
\text { Angsuran pertahun }=P x \frac{\frac{i}{12}}{1-\left(\frac{1+i}{12}\right)-t}
$$

Untuk perincian perhitungan angsuran dan biaya bunga dapat dilihat pada tabel 2 berikut ini:

\section{Biaya Variabel}

Biaya variabel adalah biaya yang selalu berubah selama proses produksi berlangsung. Dalam penelitian usaha ini, biaya variabel yang dikeluarkan antara lain untuk kebutuhan modal kerja dan pajak penghasilan usaha.

a) Kebutuhan Modal Kerja

Komponen biaya variabel yang termasuk dalam proses produksi menu masakan dalam periode tahunan dapat dilihat pada tabel 3 .

b) Pajak Penghasilan Usaha

Beban pajak yang harus dibayar didasarkan pada laba perusahaan yang diperoleh setiap tahunnya. Untuk mengetahui besarnya nilai pajak penghasilan yang harus dibayar tiap tahun. Oleh karena usaha depot memperoleh pendapatan yang tidak menentu tiap tahunnya maka besarnya pajak penghasilan yang dikeluarkan selalu mengikuti dan tidak 
sama tiap tahunnya. Contoh: jika laba bersih usaha pada tahun pertama diasumsikan sebesar Rp. 13.487.781,-

Pajak Pendapatan Usaha $=\quad 10 \% \times$ Rp. 13.487.781,-

$=\quad$ Rp. 1.348.778,-

\section{Arus Penerimaan}

Penerimaan dalam arus kas dalam hal ini merupakan seluruh komponen yang dapat digolongkan sebagai pendapatan dalam kegiatan usaha perusahaan. Komponen penerimaan tersebut dapat meliputi hasil penjualan perusahaan, penerimaan lain-lain, dan modal pinjaman.

Tabel 1 : Proyeksi Biaya Variabel Kebutuhan Modal Kerja

\begin{tabular}{|r|l|r|r|r|r|r|}
\hline No & \multicolumn{1}{|c|}{ Komponen Biaya } & Tahun 1 & \multicolumn{1}{c|}{ Tahun 2 } & \multicolumn{1}{c|}{ Tahun 3 } & \multicolumn{1}{c|}{ Tahun 4 } & \multicolumn{1}{c|}{ Tahun 5 } \\
\hline 1 & Beras & $10,168,560$ & $11,185,416$ & $12,303,958$ & $13,534,353$ & $14,887,789$ \\
\hline 2 & Menu Kepiting & $227,223,656$ & $249,946,021$ & $274,940,623$ & $302,434,686$ & $332,678,154$ \\
\hline 3 & Menu Ikan Gurami/Kakap & $49,393,854$ & $54,333,239$ & $59,766,563$ & $65,743,219$ & $72,317,541$ \\
\hline 4 & Menu Burung Dara & $50,752,784$ & $55,828,062$ & $61,410,869$ & $67,551,956$ & $74,307,151$ \\
\hline 5 & Menu Kol Nenek & $6,833,643$ & $7,517,008$ & $8,268,709$ & $9,095,579$ & $10,005,137$ \\
\hline 6 & Kuah Kaldu & 870,000 & 957,000 & $1,052,700$ & $1,157,970$ & $1,273,767$ \\
\hline 7 & Minyak Goreng & $15,103,200$ & $16,613,520$ & $18,274,872$ & $20,102,359$ & $22,112,595$ \\
\hline 8 & Gula Pasir & $6,264,000$ & $6,890,400$ & $7,579,440$ & $8,337,384$ & $9,171,122$ \\
\hline 9 & Jeruk Manis & $4,176,000$ & $4,593,600$ & $5,052,960$ & $5,558,256$ & $6,114,082$ \\
\hline 10 & Teh Kotak & 870,000 & 957,000 & $1,052,700$ & $1,157,970$ & $1,273,767$ \\
\hline 11 & Biaya LPG 12kg & $26,448,000$ & $29,092,800$ & $32,002,080$ & $35,202,288$ & $38,722,517$ \\
\hline 12 & Plastik/Kresek Kecil & 435,000 & 478,500 & 526,350 & 578,985 & 636,884 \\
\hline 13 & Plastik/Kresek Sedang & 522,000 & 574,200 & 631,620 & 694,782 & 764,260 \\
\hline 14 & Kertas Nasi & $1,078,800$ & $1,186,680$ & $1,305,348$ & $1,435,883$ & $1,579,471$ \\
\hline 15 & Plastik Klip & 957,000 & $1,052,700$ & $1,157,970$ & $1,273,767$ & $1,401,144$ \\
\hline 16 & Plastik Bening Sedang & $1,914,000$ & $2,105,400$ & $2,315,940$ & $2,547,534$ & $2,802,287$ \\
\hline 17 & Sedotan & 522,000 & 574,200 & 631,620 & 694,782 & 764,260 \\
\hline 18 & Tisu Makan & 609,000 & 669,900 & 736,890 & 810,579 & 891,637 \\
\hline 19 & Sabun Cuci Piring & 372,360 & 409,596 & 450,556 & 495,611 & 545,172 \\
\hline 20 & Sabun Cuci Tangan & 849,120 & 934,032 & $1,027,435$ & $1,130,179$ & $1,243,197$ \\
\hline 21 & Sabun Pembersih Lantai & 515,040 & 566,544 & 623,198 & 685,518 & 754,070 \\
\hline 22 & Biaya Air & $1,440,000$ & $1,584,000$ & $1,742,400$ & $1,916,640$ & $2,108,304$ \\
\hline 23 & Biaya Listrik & $2,400,000$ & $2,640,000$ & $2,904,000$ & $3,194,400$ & $3,513,840$ \\
\hline & Total Biaya Variabel & $\mathbf{4 0 9 , 7 1 8 , 0 1 7}$ & $\mathbf{4 5 0 , 6 8 9 , 8 1 8}$ & $\mathbf{4 9 5 , 7 5 8 , 8 0 0}$ & $\mathbf{5 4 5 , 3 3 4 , 6 8 0}$ & $\mathbf{5 9 9 , 8 6 8 , 1 4 8}$ \\
\hline
\end{tabular}

Sumber : Pengolahan Data Aspek Keuangan Perusahaan

1. Hasil Penjualan.

Adapun rincian penerimaan dari proyeksi hasil penjualan dapat dilihat pada tabel 4 dan 5

Asumsi penjualan yang digunakan perusahaan menurut tabel diatas bahwa pendapatan perbulan didasarkan pada asumsi pendapatan perhari. Dalam kondisi terendah asumsi pihak perusahaan mampu menjual setidaknya minimal 2 porsi dari masing-masing menu maka akan memperoleh pendapatan satu hari sebesar rp. 1.324.000,- sehingga dalam bulan juli 2013 asumsi pendapatan dari penjualan selama 29 hari sebesar rp. 38.396.000,-.

Untuk selanjurnya untuk perolehan nilai pendapatan bulan berikutnya pihak perusahaan mengasumsikan penjualan mengalami kenaikan sebesar $2 \%$ dari sebelumnya secara konstan sehingga pendapatan depot mengalami kenaikan pula. Jika pihak depot mampu menaikkan target penjualan sebesar $2 \%$ secara konstan tiap bulan maka total pendapatan satu tahun selama periode 2013-2014 adalah sebesar rp. 514.970.597,-- 
2. Modal Pinjaman

Seperti yang telah dijelaskan diatas bahwa kriteria investasi depot menggunakan 2 skenario, skenario ke-I adalah menggunakan modal pinjaman bank sebesar $100 \%$ dari nilai investasi dan skenario ke-2 menggunakan modal sendiri. Untuk menutup biaya investasi maka pinjaman dari bank diasumsikan sebesar Rp. 50.016.600,-

Tabel 2: Proyeksi Penjualan Perusahaan ( Juli 2013 - Juni 2014)

\begin{tabular}{|c|c|}
\hline Periode & Penjualan (Rp) \\
\hline Juli & $38,396,000$ \\
\hline Agustus & $39,163,920$ \\
\hline September & $39,947,198$ \\
\hline Oktober & $40,746,142$ \\
\hline November & $41,561,065$ \\
\hline Desember & $42,392,287$ \\
\hline Januari & $43,240,132$ \\
\hline Februari & $44,104,935$ \\
\hline Maret & $44,987,034$ \\
\hline April & $45,886,774$ \\
\hline Mei & $46,804,510$ \\
\hline Juni & $47,740,600$ \\
\hline Total & $\mathbf{5 1 4 , 9 7 0 , 5 9 7}$ \\
\hline
\end{tabular}

Tabel 3: Hasil Analisis Laba Rugi Perusahaan

\begin{tabular}{|c|c|c|c|}
\hline No & Tahun & Skenario 1 & Skenario 2 \\
\hline 1 & 2013 & 4.128 .631 & 12.139 .002 \\
\hline 2 & 2014 & 7.964 .173 & 16.190 .135 \\
\hline 3 & 2015 & 10.753 .590 & $20.646 \mathrm{~J} 80$ \\
\hline 4 & 2016 & 14.554 .347 & 25.548 .250 \\
\hline 5 & 2017 & 18.722 .733 & 30.940 .307 \\
\hline \multicolumn{2}{|c|}{ Rata-rata } & 11.224 .695 & 21.092 .815 \\
\hline
\end{tabular}

Sumber : Pengolahan Data Aspek Keuangan Perusahaan

\section{Analisis Laba Rugi}

Berdasarkan perhitungan analisis laba rugi yang diperoleh menunjukkan adanya perbedaan nilai yang dipengaruhi oleh dua rencana skenario penggunaan modal dalam biaya investasi. Sehingga laba usaha per tahun dari masing-masing skenario mencapai nilai yang tidak sama, perolehan laba pada skenario 1 menjadi lebih kecil dibandingkan perolehan laba pada skenario 2 .

Hal ini dipengaruhi oleh beban hutang atas modal pinjaman dengan tingkat bunga (disconnt factor) sebesar 10,6\%. Pada rata-rata perkiraan kenaikan penjualan $10 \%$ per tahun maka dapat ditentukan taksiran laba rugi pada masing-masing skenario dengan rincian perhitungan seperti pada tabel 6 berikut ini :

\section{Analisis Kriteria Nilai Investasi}

Untuk hasil analisis kriteria nilai investasi menurut masing-masing metode seperti yang tersebut diatas disajikan pada tabel 7 dibawah ini : 
Tabel 4 : Hasil Analisis Kriteria Nilai Investasi

\begin{tabular}{|c|c|c|c|}
\hline No & $\begin{array}{c}\text { Kriteria } \\
\text { Kelayakan }\end{array}$ & Syarat Kelayakan & Hasil Penilaian \\
\hline 1 & NPV & NPV $>0$ & Rp. 19.026.264 \\
\hline 2 & IRR & IRR $>$ ROR & $22,86 \%$ \\
\hline 3 & PI & PI $>1$ & 1,38 \\
\hline 4 & PP & PP < Jangka Waktu & 3 tahun 2 bulan \\
\hline 5 & BEP & BEP < Jangka Waktu & 3 tahun 5 bulan \\
\hline
\end{tabular}

Sumber : Pengolahan Data Aspek Keuangan Perusahaan

Dari tabel 4 diatas dapat dilihat hasil perhitungan kriteria kelayakan investasi menurut masing-masing kriteria bahwa untuk nilai NPV sebesar Rp. 19.026.264,- menunjukkan tambahan manfaat yang dapat diperoleh Depot Aming Genteng Surabaya selama jangka waktu proyek. Dari nilai NPV positif tersebut maka dapat disimpulkan bahwa usaha depot tersebut layak dijalankan. Untuk perhitungan nilai NPV selama umur proyek.

Berdasarkan hasil perhitungan diperoleh nilai ERR sebesar 22,86\%. Nilai tersebut sesuai dengan syarat kelayakan yaitu IRR > ROR artinya nilai tingkat pengembalian investasi usaha lebih besar daripada nilai suku bunga yang diisyaratkan sebesar 10,6\% jika investasi dilakukan di bank. Untuk itu usaha depot tersebut layak untuk dijalankan. Rincian perhitungan interpolasi nilai kriteria IRR

Pada analisis Profitability Index atau PI diperoleh'nilai sebesar 1,38 lebih besar dibandingkan syarat kelayakan, PI > 1 . Artinya jika setiap Rp. 1,- biaya yang dikeluarkan maka akan menghasilkan manfaat sebesar 1,38 sehingga manfaat yang diperoleh lebih besar dari biaya yang dikeluarkan, dengan demikian usaha depot tersebut layak untuk dijalankan.

Berdasarkan tingkat waktu pengembalian investasi Payback Period (PP) menunjukkan jangka waktu selama 3 tahun 2 bulan, lebih kecil daripada umur proyek selama 5 tahun. Hal ini berarti usaha depot tersebut layak dijalankan karena mampu mengembalikan modal investasi sebelum umur proyek berakhir.

Hasil analisis BEP diperoleh nilai lama waktu pengembalian atau titik impas selama 3 tahun 5 bulan. Nilai tersebut menunjukkan bahwa titik impas atau pulang pokok dari investasi dapat dicapai sebelum umur proyek berakhir sehingga dalam kriteria ini usaha depot tersebut dinilai layak untuk dijalankan.

\section{Analisis Sensitivitas}

Pada perhitungan analisis sensitivitas digunakan beberapa parameter penting yang berhubungan dengan penerimaan dan biaya terhadap perubahan yang terjadi. Dalam penelitian ini terdapat dua hal yang dijadikan parameter perubahan guna mengetahui hasil kriteria investasi yang merujuk pada perhitungan analisis laba rugi.

Hasil analisis sensitivitas berdasarkan kriteria NPV dan IRR menggunakan metode trial and error, dapat dilihat pada tabel 8 berikut :

Tabel 5 : Hasil Analisis Sensitivitas Perusahaan

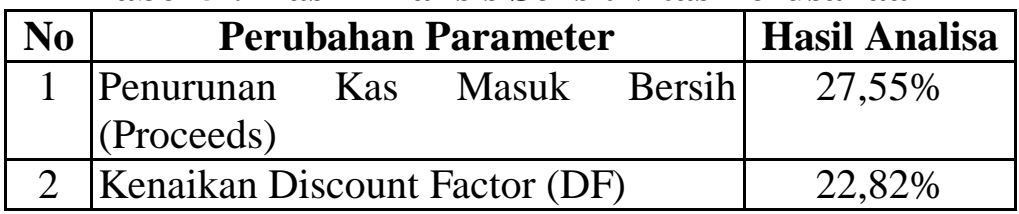

Sumber : Pengolahan Data Aspek Keuangan Perusahaan 
Dari tabel diatas diketahui bahwa batas maksimum penurunan proceeds sebesar 27,55\%. Hal ini berarti bahwa jika nanti selama umur proyek terjadi perubahan seperti kenaikan harga bahan baku, biaya produksi atau penurunan omzet penjualan yang dapat mempengaruhi penurunan proceeds pada angka 27,55\% maka nilai NPV $=0$, melebihi angka maksimal tersebut maka usaha dinilai tidak memberikan manfaat atau bahkan menimbulkan kerugian.

Sedangkan untuk parameter kenaikan tingkat suku bunga (DR) pada angka 22,82\% menunjukkan bahwa pada skenario 1 jika menggunakan modal pinjaman maka biaya modal maksimal yang dapat ditoleransi sebaiknya berada dibawah angka $22,82 \%$ pada saat NPV $=0$, jika tidak nantinya biaya modal dari usaha tersebut berpotensi mengalami kerugian.

Dengan demikian dapat diketahui jika pada skenario 1 untuk modal pinjaman terbukti bahwa adanya kenaikan tingkat suku bunga atas biaya modal lebih sensitif mempengaruhi kelayakan usaha.

Sedangkan untuk perubahan kenaikan bahan baku, biaya produksi maupun penurunan omzet penjualan bukan berarti dapat dikesampingkan, hanya saja selama perubahan biayabiaya masih dapat tertutupi dan pendapatan dapat ditingkatkan sehingga nilai proceed masih dalam batas wajar terhadap kelangsungan usaha.

Pada skenario 1 (modal pinjaman) memberikan gambaran angka maksimal dari kenaikan bahan baku sebesar $11 \%$, dimana jika terjadi kenaikan bahan baku lebih tinggi dari nilai tersebut maka usaha perusahaan berpotensi mengalami kerugian. Sehingga pada kondisi seperti ini minimal kenaikan omzet penjualan yang harus dicapai tiap tahun adalah sebesar 9,24\% agar perusahaan tidak rugi. Sedangkan hasil analisis sensitivitas pada skenario 2 (modal sendiri) untuk batas maksimal kenaikan biaya bahan baku sebesar 11,54\% terbukti masih dapat ditoleransi dengan catatan bahwa pada kondisi tersebut usaha depot dapat menaikkan omzet penjualan minimal $8,73 \%$ agar kelangsungan usaha tetap stabil.

\section{KESIMPULAN}

Hasil analisis aspek finansial membuktikan bahwa usaha ini layak dijalankan, berdasarkan perhitungan nilai kriteria investasi menurut skenario 1 menggunakan modal pinjaman untuk biaya investasi menunjukkan nilai NPV $=\mathrm{Rp} .19 .026 .264,-\mathrm{IRR}=22,86 \%$, $\mathrm{PI}=1,38, \mathrm{PP}=3$ tahun 2 bulan dan $\mathrm{BEP}=3$ tahun 5 bulan. Sedangkan untuk hasil analisis sensitivitas menunjukkan bahwa nilai perubahan parameter kenaikan tingkat suku bunga atas biaya modal pinjaman terbukti lebih sensitif mempengaruhi kelayakan usaha, artinya jika usaha menggunakan modal pinjaman selama tingkat suku bunga dibawah $22,82 \%$ maka usaha depot masih layak dijalankan. Jika usaha depot dijalankan menggunakan skenario 2 yaitu modal sendiri menunjukkan bahwa usaha tersebut layak dijalankan atas dasar perhitungan laba rugi dan arus kas yang menunjukkah nilai lebih tinggi dibandingkan menggunakan skenario 1 karena tidak dibebani oleh beban modal pinjaman.

\section{DAFTAR PUSTAKA}

Alhusna, Galuh Gumelar. 2011. Analisis Kelayakan Bisnis Usaha Kedai Kopi Mobile Di Wilayah Kota Bogor. Skripsi. Bogor : FEM-IPB.

Daengs, Heri. 2013. Analisis Kelayakan Bisnis Pada Perencanaan Usaha Café Kuliner Di Surabaya, Penelitian, Surabaya, Universitas 45.

Endah, P. Lucia dan P, Syari. 2007. Sukses Mengelola Usaha Warung Makan. Cetakan Pertama. Jakarta : Transmedia. 
Gray, C.F dan Larson, E.W. 2007. Manajemen Proyek. Edisi 3. Yogyakarta : Andi.

Husnan, Suad dan Suwarsono. 2000. Studi Kelayakan Proyek : Konsep, Teknik dan Penyusunan Laporan. Yogyakarta: UPP AMP YKPN.

Ibrahim, Yacob H.M. 2009. Studi Kelayakan Bisnis. Edisi Revisi. Jakarta : Rineka Cipta.

Johan, S. 2011. Studi Kelayakan Pengembangan Bisnis. Yogyakarta : Graha Ilmu.

Kasmir dan Jakfar. 2003. Studi Kelayakan Bisnis. Edisi Kedua. Cetakan ke-4. Jakarta: Kencana Prenada Media Group.

Kasmir dan Jakfar. 2009. Studi Kelayakan Bisnis. Edisi ke-2. Jakarta : Kencana Prenada Media Grup.

Kotler, Philip. 2007. Manajemen Pemasaran, Analisis Perencanaan, Pengendalian. Edisi Bahasa Indonesia. Jakarta : Salemba Empat

Prassetya, Aridha. 2010. Manajemen Pemasaran. Cetakan Pertama Surabaya : DHD' 45 Jawa Timur.

Radityo, 2009. Analisis Kelayakan Usaha Pendirian Rumah Makan "Bu SRI". Tugas Akhir. Jakarta : Gunadarma.

Rivai, Arief. 2009. Analisis Kelayakan Usaha Penggemukan Sapi Potong (Fattening) Pada PT Zagrotech Dafa International (ZDI) Kecamatan Ciampea Kabupaten Bogor. Penelitian. Bogor : FEM-IPB.

Sutojo, Siswanto. 2000. Studi Kelayakan Proyek : Konsep, Teknik dan Kasus. Cetakan Pertama. Jakarta : Damar Mulia Mustika. 